\title{
Historical fluctuations in spawning location of anchovy (Engraulis encrasicolus) and sardine (Sardina pilchardus) in the Bay of Biscay during 1967-73 and 2000-2004
}

\author{
Edwige Bellier, Benjamin Planque* and Pierre Petitgas
}

IFREMER, Département Ecologie et Modèles pour l'Halieutique, rue de l'île d'Yeu, BP21105, 44311 Nantes Cedex 3, France

*: Corresponding author : benjamin.planque@ifremer.fr

\begin{abstract}
:
The spatial extent of small pelagic fish spawning habitat is influenced by environmental factors and by the state of the adult population. In return, the configuration of spawning habitat affects recruitment and therefore the future structure of the adult population. Interannual changes in spatial patterns of spawning reflect variations in adult population structures and their environment. The present study describes the historical changes in the spatial distribution of spawning of anchovy (Engraulis encrasicolus) and sardine (Sardina pilchardus) in the Bay of Biscay during two periods: 1967-72 and 2000-2004. Using data from egg surveys conducted in spring, the spatial distributions of anchovy and sardine eggs are characterized by means of geostatistics. For each survey, a map of probability of egg presence is constructed. The maps are then compared to define (1) recurrent spawning areas, (2) occasional spawning areas and (3) unfavourable spawning areas during each period. Sardine spawning habitat is generally fragmented and appears spatially limited by the presence of cold bottom water. It is confined to coastal or shelf break refuge areas in years of restricted spawning extent. For anchovy, recurrent spawning sites are found in Gironde and Adour estuaries whilst spawning can extend further offshore in years of more intense spawning. For both species, the mean pattern of spawning has changed between 1967-72 and 2000-2004. Noticeably, the spatial distribution of anchovy eggs in spring has expanded northward. This trend possibly results from changes in environmental conditions during the last four decades.
\end{abstract}




\section{INTRODUCTION}

Most pelagic fish species, and in particular anchovy and sardine in upwelling systems, undergo large interannual and interdecadal fluctuations in abundance (Cury, 1988, Lluch-Belda et al., 1989, Schwartzlose et al., 1999). Anchovy and sardine have a

5 central place in upwelling ecosystems where they constitute an important part of commercially exploited species, and play a role as forage fish for numerous predator such as large pelagic fish, demersal fish, sea birds and mammals (Anonymous, 1997). This role has been emphasised in Cury et al. (2000) who describe small pelagics as midtrophic "wasp-waist" populations which exert a major control on the dynamics of upper

10 and lower trophic levels in upwelling ecosystems.

Different hypotheses have been suggested to explain interannual and long term variations in fish abundance which are often attributed to important variability in recruitment levels, and are ultimately linked to variations in ocean processes (Motos, 1996, Hammann et al., 1998, van der Lingen et al., 2001, Lynn, 2003, Stradoudakis et al., 2003). Following Hjort's critical period hypothesis (Hjort, 1914) which attributes fluctuations in population abundance to variations in fish survival during a short period of their early life history, Cushing (1975) proposed the "match-mismatch" hypothesis in which recruitment success depends on the synchrony between spawning and planktonic production. Cury \& Roy (1989) show that in upwelling systems early stage survival, i.e. recruitment, is generally maximised when wind speed is constrained within a defined range which they termed the "optimal environmental window". Bakun (1996) proposed that recruitment be controlled by three major class of physical ocean process, the 'ocean triad': enrichment, concentration and retention, which when combined, provide favourable reproductive habitat for coastal pelagic fish (Bakun, 1996, Agostini and

25 Bakun, 2002). In the "member-vagrant" hypothesis (Sinclair,1988), the abundance of fish is spatially dependent and is related to the size of the spawning area and the extent of the region suitable for individuals during their early life stages (eggs and larvae). The idea common to the above mentioned studies is that timing and location of spawning is critical to the fate of the eggs and larvae and therefore to subsequent recruitment success or failure.

The spatial and temporal extent of spawning is itself constrained by environmental conditions as well as by the state of the adult populations. In his "basin model", 
MacCall (1990) shows that, as a result of density dependence, habitat selection can vary as a function of adult population size and population demographic structure. Other studies argues that habitat selection is equally constrained by environmental conditions, most often temperature (see e.g. Checkley et al., 2000, van der Lingen et al., 2001).

5 In summary, the spatial extent of spawning is influenced by environmental factors (biotic and abiotic) and by the state of the adult population, and in return it affects recruitment and therefore the future structure of adult population. It is thus of primary importance to accurately describe the geographical extent of spawning areas and their degree of natural variability to understand the mechanisms responsible for large

10 interannual variability in small pelagic fish populations.

The present work focuses on the study of spawning habitats of sardine (Sardina pilchardus) and anchovy (Engraulis encrasicolus) in the Bay of Biscay. The spatial distribution of sardine expands from the western African coast (Furnestin and Furnestin, 1959, Ettahiri et al., 2003) to southern Norway (Parrish et al., 1989) and anchovy

15 expands from western Africa $\left(5^{\circ} \mathrm{N}\right)$ to the northern North Sea (Reid, 1966). As in other pelagic ecosystems the two species coexist and spawn in the Bay of Biscay. Anchovy and sardine display large interannual variability in adult abundance and recruitment (Junquera, 1986, Borja et al., 1996, Uriarte et al., 1996, Allain et al., 2001, Guisande et al., 2001). Arbault \& Lacroix $(1971,1977)$ described for the first time the spawning area of sardine and anchovy over most of the Bay of Biscay continental shelf throughout the year. They defined the period of spawning for these two species with anchovy spawning from April to July and sardine from February to November with a maximal intensity in May and June respectively. The extent of anchovy spawning area displays high interannual variability as shown by Motos et al. (1996), while

25 Stratoudakis et al. (2003) observed a decline in the spatial extent of the spawning area of sardine in the north-west of the Iberian Peninsula during the 1990's. According to previous studies conducted in European waters (Motos et al., 1996, Somarakis et al., 2004, Uriarte et al., 1996 ), anchovy populations appears to have density-dependent strategies of spawning area selection.

30 Here, we investigate the spatial distribution of sardine and anchovy spawning during two periods: $1967-1972$ and 2000-2004. Our aim is to characterise spawning habitat and to define (1) recurrent spawning areas, where spawning is observed every year, (2) occasional spawning areas, where the probability of spawning varies greatly from year 
to year and (3) unfavourable spawning areas, where spawning is almost never observed. In addition we compare changes in the major characteristics of spawning spatial extent during the 2 periods to provide a first description of possible long-term changes in spawning dynamics of the two species. 


\section{DATA AND METHOD}

\section{Historical cruises 1967-1972}

During the period 1964-1974 a series of cruises was carried out by the ISTPM (Institut Scientifique et Technique des Pêches Maritimes) to investigate the hydrological, zoo-

5 and icthyo-planktonic characteristics of the Bay of Biscay continental shelf. For each season, a survey was conducted following a network of stations over the entire shelf (Fig. 1), from Brittany to the Cantabrian Sea. The plankton samples were collected using a Hensen net $\left(0.38 \mathrm{~m}^{2}\right.$ aperture $)$ vertically towed from the bottom $(100 \mathrm{~m}$ maximum) to the surface at the speed $0.3 \mathrm{~m} \cdot \mathrm{s}^{-1}$ (Arbault and Lacroix, 1971, 1977). For

10 each sample, eggs were identified to species level (for anchovy, sardine and sprat) and counted. Abundance were subsequently transformed to number of eggs per $\mathrm{m}^{2}$.

The original data, available in hand written format, have recently been digitised and compiled in a database. However, for some cruises the original paper documents could not be retrieved. The data used here correspond to spring cruises for the years 1967 and 1969-1972 (see Fig. 2).

\section{PELGAS cruises 2000-2004}

In 2000, a new series of cruises called PELGAS (Pelagic Gascogne) was initiated, taking place onboard $\mathrm{R} / \mathrm{V}$ Thalassa. These cruises take place each year in spring and their primary objective is to contribute to the evaluation of small pelagic fish

20 populations in the Bay of Biscay by acoustic methods. Additional measurements and sampling are conducted to study hydrology (temperature, salinity), plankton (chlorophyll, micro and mesozooplankton), icthyoplankton (fish eggs and larvae), fish biological traits (size, maturity,...), and top predators (marine birds and mammals).

Fish eggs are collected using the Continuous Underway Fish eggs sampler (CUFES), a system that was first developed to sample eggs of Atlantic menhaden (Checkley et al., 1997). The CUFES consists of a submersible, high volume pump mounted outboard of the vessel and can be used in practically all condition of sea and whilst vessel is both in station or underway. Seawater is continuously pumped at $3 \mathrm{~m}$ depth at rate of approx. $500 \mathrm{l} / \mathrm{min}$. Eggs are then concentrated in an oscillating net (500 $\mu \mathrm{m}$ mesh size) where

30 the flow is reduced to a minimal value (approx. 20 1/min). Eggs are then retained into a collector (500 $\mu \mathrm{m}$ mesh size). Samples are collected every 3 miles (20 minutes). The 
volume of seawater pumped during 20 minutes corresponds to approximately $10 \mathrm{~m}^{3}$. Eggs are identified to species level for anchovy and sardine, counted onboard and then preserved in $4 \%$ formaldehyde solution. Abundance are subsequently transformed to number of eggs per $\mathrm{m}^{3}$.

5 The CUFES sampling methodology was preferred to that of vertical plankton net as it permits sampling during acoustic surveying which needs to be carried at vessel speed of approx. 10 knots $\left(5 \mathrm{~m} \cdot \mathrm{s}^{-1}\right)$.

\section{Consistency of data series}

The change in sampling methodology between the two periods (1967-72 and 2000-04)

10 implies that the egg data are of slightly different nature. Whilst Hensen net provides vertically integrated egg abundance, CUFES provides egg concentration horizontally integrated at a given depth $(3 \mathrm{~m})$. There is no simple way to transform one type of data to match the other. However, if one assumes that most eggs are concentrated in the upper $10 \mathrm{~m}$ (this is a reasonable assumption following the results of Boyra et al. (2003),

15 the volume of water containing eggs effectively sampled by the Hensen net is $3.8 \mathrm{~m}^{3}$. If one further assumes that the egg concentration at $3 \mathrm{~m}$ is close to the average of the $0-10$ $\mathrm{m}$ layer, the volume sampled by the CUFES in the same body of water is of about 10 $\mathrm{m}^{3}$. We can therefore accept at first approximation that a CUFES sample corresponds to 2.6 times more water filtered than a Hensen sample.

20 To limit discrepancy due to differences of sampling methodology, the analyses were restricted to egg presence/absence. During the PELGAS cruises, it was observed that egg presence/absence from vertically integrated plankton samples (using a WP2 plankton net) was coherent with egg presence/absence from nearby CUFES samples. Other possible consequences of changes in egg sampling methodology are further considered in the Discussion section.

\section{Spatial analyses}

The cartography of anchovy and sardine egg distributions is realised using geostatistical interpolation technique known as Kriging (Matheron, 1962, Cressie, 1993). The method consists in calculating weighted means of original observations, with weights derived from knowledge on the spatial structure of the data. The spatial structure is described from the variogram function. 
The experimental variogram represents the semivariance between data points as a function of the spatial distance between them (Matheron, 1962). The experimental variogram is calculated using the following equation:

$$
\gamma(h)=\frac{1}{2 n(h)} \sum_{i}^{n(h)}\left[Z\left(x_{i}\right)-Z\left(x_{i}+h\right)\right]^{2}
$$

5 where $\chi(h)$ represents the experimental variogram for distance $h, n(h)$ is the number of pairs of observations separated by distance $h, Z\left(x_{i}\right)$ is the observed value at location $x_{i}$ and $Z\left(x_{i}+h\right)$ is the observed value at a distance $h$ from location $x_{i}$.

Because the statistical distribution of egg concentration is highly skewed towards low values (approximately 50\% of total values are zeros), the spatial structure of eggs is difficult to describe with variograms calculated from the raw data. Instead, the experimental variograms have been calculated on binary-transformed data (presence/absence). Presence (coded one) was considered when egg concentration was greater than 1 (for the period 1967-74) or 2.6 (for the period 2000-2004), otherwise the data were coded for absence (coded zero). Experimental variograms were calculated for each cruise and for each species.

Theoretical variograms are adjusted to experimental variograms by fitting the following exponential model :

$$
\gamma^{*}(h)=\left(P+S^{2}\right)\left(1-e^{\frac{-|h|}{a}}\right)
$$

Where $\gamma^{*}(h)$ is the theoretical variogram, $P$ is the nugget effect, $\left(P+S^{2}\right)$ is the sill and $a$ is the range. In order to take account for interannual variability in models parameter, a general function is fitted to the data (i.e. all years combined), and adjusted for interannual variability in the model parameters. This method is referred to as Generalised mixed-effects modelling (Pinheiro and Bates, 2000). Non-linear mixedeffects models (Lindstrom and Bates, 1990) are intended for grouped data in which the response can be modelled as a non-linear function of a set of co-variables (Pinheiro and Bates, 2000), which is the case for the present exponential variogram models. In our study, data are grouped by survey (years), the response variable is the variogram value and the co-variable is the distance between the sampling locations. Mixed-effect models allow some parameters to be fixed for all groups (the fixed effects) and others to vary 
between groups (the random effects). Random effects should be applied in priority to parameters with the highest between year variability. On the basis of these criteria, the exponential theoretical variogram for sardine has been defined as follows:

$$
\gamma^{*}\left(h_{i}\right)=\left(\left(P+p_{i}\right)+\left(S^{2}+s_{i}^{2}\right)\right)\left(1-e^{\left(\frac{-|h|}{a}\right)}\right)
$$

5 Where $\gamma^{*}\left(h_{i}\right)$ is the theoretical variogram for year $i, P, S^{2}$ and $a$ are the fixed effects (i.e, for all years), $p_{i}$ and $\mathrm{s}^{2}$ are the random effects (i.e., vary every year), there is no random effect for the range $a$.

For the anchovy random effects were only considered for the nugget, resulting in the following equation:

$10 \quad \gamma\left(h_{i}\right)=\left(\left(P+p_{i}\right)+S^{2}\right)\left(1-e^{\left(\frac{-|h|}{a}\right)}\right)$

Mixed effect model fits of theoretical variograms are shown in Fig. 3, based on fitted parameters in Table 1. Once the model of spatial correlation of eggs is established (above), kriging analysis can be performed. Presence/absence for anchovy and sardine eggs are interpolated by ordinary kriging (Cressie, 1993) on a regular grid of $1 / 8^{\text {th }}$

15 degree. The presence/absence indicator approach allows the estimation of the probability distribution of a variable within a region. No assumptions concerning the modelled variable (eggs distribution) are needed (Marinoni, 2003). The binary data correspond to egg presence probability measurements with values of one (presence) or zero (absence). The interpolation of these probability values gives estimators that can be interpreted as the outcome probabilities of the modelled variable (Marinoni, 2003). The result of kriging is a cartography of the probability of eggs presence for each species and each year.

For each period (1967-72 and 2000-04) and each species the mean and the standard deviation of the estimated probability of presence are calculated at every spatial location of the grid. These calculations result in an "average map" and a "variability map" for each period. The average map summarises the average spawning area whilst the variability map displays the interannual variability in spawning during each period. The 
analysis of average and variability maps can allow for the classifcation of three categories of spawning area:

1. Recurrent spawning sites : areas with high mean and low standard deviation values. Anchovy or sardine spawn every year in these sites.

5 2. Occasional spawning sites : areas with high standard deviation values. Anchovy or sardine spawn in some years but not in others in these areas.

3. Unfavourable site of spawning : areas with low mean and low standard deviation values. Sardine or anchovy almost never spawn in these areas.

Numerical methods were implemented using R (R Development Core Team, 2004) and

10 Matlab (http//www.mathworks.com/) softwares, as well as Nlme and GeoR (Ribeiro and Diggle, 2001) libraries. 


\section{RESULTS}

\section{Sardine egg distribution from 1967 to 1972}

The sardine egg distributions from 1967 to 1972 (Fig. 4) are characterised by a strong year-to-year variability with spawning area extending potentially over the whole of the

5 continental shelf of the Bay of Biscay. For example in 1970, the extent of spawning is restricted to areas along the coast from south eastern Brittany to the north of the Gironde estuary with high probability in front of the Loire estuary. Conversely, the next year (1971), the spawning area covers practically all the continental shelf. Probabilities are lower in an area located south of Brittany and extending towards the mid-shelf. This

10 area is known to host a body of cold bottom temperature water termed the "cold pool" (Vincent, 1973, Puillat et al., 2004). Low probability values are also found in the southern part of the Bay of Biscay.

Recurrent sites of spawning appear located from south-west Brittany to the north of the Gironde estuary (Fig. 5), where probability of egg presence is high and interannual variability is low. An occasional spawning area is located in front of the Gironde estuary where the average of probability of egg presence is high and the variability of egg presence is high too. And a very occasional spawning site is located along shelf break between $46^{\circ} 30^{\prime} \mathrm{N}$ and $47^{\circ} 30^{\prime} \mathrm{N}$. A non-spawning site is located south of Brittany, around $4^{\circ} \mathrm{W}$, possibly linked to the presence of cold bottom water known as the "cold pool" (Vincent, 1973, Puillat et al., 2004).

Sardine egg distribution from 2000 to 2004

As for 1967-72 there is a large degree of year-to-year variability in the spatial distribution of sardine egg presence over the Bay of Biscay continental shelf during the period 2000-04 (Fig. 4). For example in 2000, the distribution of sardine eggs extends throughout the Bay of Biscay continental shelf except a narrow site located in the area of the cold pool (Fig. 4). In 2001, The distribution of sardine is distinct from the previous year. Three large sardine spawning areas are visible, two of which are coastal (in front of Gironde estuary and along Landes coast) and the other is oceanic (along the shelf break between $46^{\circ} \mathrm{N}$ and $47^{\circ} 30^{\prime} \mathrm{N}$ ).

30 Three recurrent spawning sites (Fig. 5) appear to be located (1) south-west Brittany to the north of the Gironde estuary, (2) south of the Gironde estuary and (3) towards the 
shelf break between $46^{\circ} \mathrm{N}$ and $47^{\circ} 30^{\prime} \mathrm{N}$. Several occasional spawning sites are identified in the southern part of the Bay of Biscay. These are located along the shelf break from the southern end of the bay of Biscay up to $46^{\circ} \mathrm{N}$ and include the region known as "fer à cheval", where the continental slope turns sharply around $45^{\circ} \mathrm{N}$ (see Fig. 1).

5 The distribution of eggs seems to have evolved between 1967-74 and 2000-2004. In the recent period the modelled mean distribution of sardine eggs is more extended than during historical period, and new recurrent and occasional sardine spawning sites have appeared.

\section{Anchovy egg distribution from 1967 to 1972}

10 The distribution of anchovy eggs from 1967 to 1972 (Fig. 4) is almost always confined on the southern part of the Bay of Biscay continental shelf (except for small patches in 1967). The spatial structure of anchovy spawning area may be characterised by a "continuous area". The location and the extent of anchovy egg distribution is nevertheless variable during this period. For example in 1967, Anchovy spawning (Fig.

154 ) is located in the southern part of the Bay of Biscay up to $47^{\circ} \mathrm{N}$ and restricted to the more coastal areas from $45^{\circ} \mathrm{N}$ to $47^{\circ} \mathrm{N}$. Two small patches with lower probability also appear at the shelf break $\left(45^{\circ} 30^{\prime} \mathrm{N}\right)$ and on the central area of the shelf $\left(47^{\circ} 30^{\prime} \mathrm{N}\right)$. In 1971, the anchovy spawning area is the smallest observed with high probabilities only found close to the coast between $43^{\circ} 30^{\prime} \mathrm{N}$ and $44^{\circ} 30^{\prime} \mathrm{N}$.

20 One recurrent spawning area for anchovy (Fig. 6) is located in front of the Adour estuary, the mean probability of eggs presence is average but the variability is very low. Two occasional spawning areas are located in front of Gironde estuary and at the shelf break around $44^{\circ} \mathrm{N}$.

\section{Anchovy egg distribution from 2000 to 2004}

25 As for the period 1967-72, the spawning of anchovy is mostly restricted to the southern part of the Bay of Biscay. There is however a larger degree of interannual variability in spatial patterns, particularly in 2003 when the distribution is more scattered and covers a wider area. Two recurrent centres of anchovy spawning are identified (Fig. 6). The first is located in the southern part of the bay between the Adour and Gironde estuaries,

30 with the exception of a coastal site around $44^{\circ} 30^{\prime}$. The second is locate in front of the Gironde estuary. Occasional site of spawning are patchy and spreads over most of Bay of Biscay the continental shelf; south of $47^{\circ} \mathrm{N}$. In the recent period, anchovy average 
spawning region is more extended than in 1967-1970, and has apparently been displaced towards the North. The Gironde estuary, which was an occasional spawning site, appears now to be a recurrent centre of spawning for anchovy. 


\section{DISCUSSION}

\section{Methodological aspects}

During the historical period, the Hensen net has provided vertically integrated egg abundance for each network station (egg numbers per $\mathrm{m}^{2}$ ) whilst during the recent

5 period, CUFES has provided horizontally integrated egg concentration (eggs number per $\mathrm{m}^{3}$ ) at $3 \mathrm{~m}$ depth along transects. A major limitation in the CUFES sampling strategy is that collection of samples is performed at a fixed depth whilst vertical distribution of fish eggs may vary in space as a response to changes in environmental condition (Boyra et al., 2003). On the other hand CUFES sampling has the advantage of

10 continuously sampling eggs, resulting in enhanced characterisation of their spatial patterns despite their aggregated distributions (Checkley et al., 1997, 2000). The differences in the two sampling strategies implies that the egg data for the two periods are of slightly different nature, and consequently the comparison between eggs distribution of the two period are limited. In order to reduce this discrepancy in the two sets of data, a ratio between the two systems sampling efficiency has been calculated. This ratio (2.6) is based on approximate egg vertical distribution and sampled volumes of the two systems. Additional tests which were conducted with other ratios $(5,10,25)$ indicate that the method is robust to approximated ratio values. This results from the fact that analyses are done with binary data (presence/absence) rather than with egg concentration.

During the two periods of sampling, changes in time and duration of field cruises have occurred. The historic surveys were shorter ( $\sim 15$ days) than the Pelgas cruise $(\sim 1$ month). Hence the spawning areas derived from historical surveys are more synoptic than those derived from the Pelgas cruises. Due to logistical constraints, the Pelgas cruises have taken place at different dates (Fig. 2): $17^{\text {th }}$ April to $14^{\text {th }}$ May in 2000, $28^{\text {th }}$ April to $4^{\text {th }}$ June in $2001,10^{\text {th }}$ May to $5^{\text {th }}$ June in $2002,30^{\text {th }}$ May to $24^{\text {th }}$ June in 2003 and $27^{\text {th }}$ April to $24^{\text {th }}$ May in 2004. During the spring period, vertical stratification takes place and river runoff diminishes so that slight changes in cruise timing can have a large impact on the environmental conditions encountered. This may have artificially increased the interannual variability of egg distributions reported in the results.

The present work is based on egg presence, rather than egg abundance, to define spawning habitat. However, areas where high probability of egg presence are found may 
not necessarily match areas of high egg abundance, and the study of egg abundance spatial distribution still needs specific investigation. The non-linear method of disjunctive kriging could be envisaged to study both egg presence spatial distribution and egg abundance distribution (Petitgas, 1993, Barange and Hampton, 1997). This approach could provide an estimate of the location of spawning centres of anchovy and sardine in terms of abundance. It could also provide additional description of the spatial structure of anchovy and sardine spawning at local scale in the Bay of Biscay.

An alternative and more robust approach would have been to model explicitly the vertical distribution of fish eggs during the recent period. This could be done on the

10 basis of egg buoyancy measurements and hydrological vertical profiles (e.g. as in Boyra et al., 2003). However, such models are still under development and their application is not easily achievable yet (see discussion in Planque et al., submitted).

\section{Spatial distribution of sardine eggs}

The distribution of sardine spawning area during the period of 1967-1972 (Fig. 4) is in agreement with the published results of Arbault and Lacroix $(1971,1977)$ based on the same data except for the area located on continental shelf break on the north of Gironde estuary. This area, which does not appear clearly on the average map of probability of presence, was identified by Arbault and Lacroix on the basis of observations made in 1964, 1966, 1967, 1968 and 1971. As the data for years 1964, 1966 and 1968 were not available for the present study, the shelf break area only appears as an occasional spawning site for sardine.

During the two periods of study, the extent of the spawning area varies from year to year. However, the spawning area seems to be more extended in recent years. Sardine are patchily distributed all over the continental shelf, a result consistent with other observations in almost all pelagic ecosystems of the world. In the Benguela upwelling, sardine (Sardinops sagax) eggs are patchily distributed throughout the spawning season (van der Lingen et al., 2001). The same is observed for sardine in south California

From 1967 to 1972 sardine spawned every year at sites located from south west Brittany to the north of the Gironde estuary. This area was reported by Arbault and Lacroix $(1971,1977)$ as a rich and extended spawning area each year. This area is primarily under the influence of the Loire estuary (Koutsikopoulos and Le Cann, 1996). Spawning appears occasionally in front of the Gironde estuary which suggest that either 
environmental conditions may not be favourable every year or that spawning in this area may depend on the size of the adult population. To the north of Gironde estuary, the central region of the continental shelf appears to be unfavourable for sardine spawning. This area corresponds to the location of the "cold pool" (Vincent and Kurc, 1969a, 5 Puillat et al., 2004), a body of water where bottom temperature is low $\left(<12^{\circ} \mathrm{C}\right)$, whilst the favourable bottom temperature for sardine spawning ranges between 12 and $15^{\circ} \mathrm{C}$ (Planque et al., submitted).

For the recent period recurrent spawning sites appear to be located in three areas. First, from south west Brittany to the north of the Gironde estuary, this area was already

10 observed during the historical period. Second, south of the Gironde estuary along the coast. This area was not detected as a recurrent spawning site in historical records. It is a region characterised by spring coastal upwelling (Koutsikopoulos and Le Cann, 1996). Third, towards the shelf break between $46^{\circ} \mathrm{N}$ and $47^{\circ} 30^{\prime} \mathrm{N}$, an offshore region that was previously detected as an occasional spawning site. Two occasional spawning sites are 15 identified in the southern part of the Bay of Biscay: (1) between $45^{\circ} \mathrm{N}$ and $46^{\circ} \mathrm{N}$ in the shelf break region, and (2) between $44^{\circ} \mathrm{N}$ and $45^{\circ} \mathrm{N}$ also in the shelf break region. The sardine population seems to occupy the south of the Bay of Biscay, this did not appear in 1967-1972. For all years in the recent period, in the north of the Gironde area, the egg distribution appears to depend upon the extent of the cold pool water mass. In 2001, the unfavourable spawning area in the middle of the shelf has a lesser spatial extension than in 2002 or in 2004. Similarly the cold pool area was also less extended in 2001 than in 2002 or in 2004 (Planque et al., submitted). The possible influence of the cold pool on sardine distribution is consistent with the results of Vincent and Kurc (1969b) who proposed that year to year variability of "cold pool" could partially control sardine distribution.

These results indicate that sardine spawning habitat may be related to meso-scale hydrodynamic features such as coastal upwellings, river plumes, offshore eddies and the cold pool. Such meso-scale hydrodynamic structures display large interannual variability (Koutsikopoulos and Le Cann, 1996, Puillat et al., 2004, Planque et al., 30 submitted), as a response to fluctuations in climatic and hydrological forcing (Planque et al., 2003). Hence the interannual variability of spatio-temporal spawning dynamic seems to be essentially linked to interannual variability in meso-scale hydrodynamic structure. Such variability in sardine spawning area is also found in other regions of the 
world. In the south of California, Lynn (2003) shows that large interannual variation in the pattern and density of Pacific sardine eggs are clearly related to concurrently observed patterns of surface temperature. In Northwest of Iberian peninsula, Stratoudakis et al (2003) observed a decline of sardine spawning area links to change of sea surface temperature during the 1990s. Therefore mesoscale physical process, may favour survival of early stages of sardine, due to increased primary production and its transfer to higher trophic levels (González-Quirós et al., 2004, Logerwell and Smith, 2001).

\section{Spatial distribution of anchovy eggs}

10 For the period 1967-72 the distribution of anchovy spawning area agrees with the description of Arbault and Lacroix (1971, 1977). The anchovy spawning area is confined to the southern part of the Bay of Biscay $\left(<46^{\circ} 5^{\prime} \mathrm{N}\right)$, although the location and spatial extent of egg presence are variable during the period. The spatial extent of spawning shows greater spatial-temporal variability during the recent period. For the

15 two periods of study, the spatial structure of anchovy spawning may be characterised by a "continuous area". However, the anchovy egg distribution in 2003 appears distinct from the other years. The anchovy spawning area was fragmented and distributed throughout the bay of Biscay south of 4730'N. In 2003 the Pelgas cruise took place in June, i.e. later than in other years. In addition spring 2003 was also marked by strong thermal stratification due to intense solar heating, a situation more typical of summer. The observed pattern of anchovy spawning distribution in spring 2003 may therefore corresponds to a distribution later in the season. The distribution is then consistent with the pattern of concentration/expansion, with anchovies concentrating in the spawning ground at the begining of spawning period, and dispersing afterwards to occupy the whole Bay of Biscay (Arbault and Lacroix, 1977, Motos et al., 1996). The apparent lack of anchovy eggs in front of the Gironde estuary is also related to the particular hydrographic conditions during the cruise. Although no eggs were sampled by CUFES, additional vertical plankton hauls which were conducted during the survey showed that eggs were actually present in the area, but probably at a depth not sampled by CUFES.

30 For the historical period, one recurrent spawning area for anchovy is located in front of Adour estuary, and two occasional spawning areas are located in front of Gironde estuary and at the shelf break around $44^{\circ} \mathrm{N}$. For the recent period, the recurrent spawning areas are located close to the main southern estuaries: Gironde and Adour. 
Some spawning habitats located in oceanic area appear which were not observed during historical period. Nowadays, anchovy average spawning region is more extended than in 1967-1972, and has apparently been displaced northward, possibly as a result of environmental changes. In fact, the 1990s were characterised by warmer temperature 5 than during the rest of the $20^{\text {th }}$ century (Planque et al., 2003).

The Gironde and Adour estuaries seem to be favourable spawning habitats for anchovies. In fact, estuaries are favourable anchovy spawning habitat in most regions of the world; (Reid, 1966, Arbault and Lacroix, 1977, Motos et al., 1996, Agostini and Bakun, 2002, Lloret et al., 2004). These areas possess the propriety of the "ocean triad"

10 of enrichment, concentration and retention (Bakun, 1996, Agostini and Bakun, 2002). Enrichment coming from the nutrient rich fresh water input, concentration occurring in the haline fronts, and retention existing over the shelf in front of the river plumes (Allain et al., 2003) or nearby offshore slope water eddies (Pingree and Le Cann, 1992). The spatial organisation of these oceanic processes tends to maintain anchovy spawning confined close the coast.

Coastal and oceanic spawning areas correspond to different components of the anchovy population. The oceanic spawning habitat is principally associated with large individuals, aged 2 or more years (Motos et al., 1996), while in front of Gironde estuary anchovy size and age distribution may vary (Petitgas et al., 2003).

20 In 1970, the spawning area greatly decreased and 1971 had the smallest spawning area observed during this historical period. These two years were unfavourable for anchovies spawning. In 1971, the favourable temperature for spawning is observed only in the region where spawning occurs (Arbault and Lacroix, 1977). Junquera (1986) and Uriarte et al. (1996) reported a decrease in anchovy catch in 1970s in Bay of Biscay.

25 For the preceding year of 1970, the values of recruitment and upwelling indices are low (Borja et al., 1996, Borja et al., 1998). The anchovy population underwent low levels of recruitment associated with unfavourable environmental conditions for recruitment success and spawning. This association between a spatially restricted region of favourable temperature and a reduction in adult population size could explain this great 30 reduction in spawning area. Previous study (Motos et al., 1996, Uriarte et al., 1996) suggested that spatial distribution patterns of anchovy can change depending on the level of adult abundance. In years with high adult abundance (1990, 1992), eggs cover most of the sampling area. On the contrary, in years of low adult abundance (1989, 
1991), eggs occur in discrete aggregations centred on the principal spawning centres, such as the Gironde and Adour estuaries. Accordingly in European waters, relationship between egg production and daily specific fecundity implies density dependence use of spawning habitat by anchovy (Somarakis et al., 2004). Nevertheless, a comparison of egg presence and adult biomass derived from acoustic measurements at the time of sampling (during the period 2000-2004) does not confirm the relationship between adult abundance and egg presence in the Bay of Biscay for sardine nor for anchovy (Planque et al. submitted).

The variability map of the recent period confirms the existence of two centres of

10 anchovy spawning in front of the Gironde and Adour estuaries (Motos et al., 1996). As the result of interannual variability of spatial spawning dynamics, the anchovy spawning area can contract or expand between years, but a centre of spawning always persists. Brown (1984) argues that in most cases the abundance and distribution of a species is determined by many physical and biotic variables which create a continuous

15 habitat that approximately follows a Gaussian shape. The geographic structure and characteristics of the anchovy spawning habitat permit linking variability of spatiotemporal spawning dynamics with the "basin model" theory (MacCall, 1990). The basin model is best suited to population with a central periphery density gradient. The basin model describes a potential relationship between geography, movement and growth dynamics at the population level. The "basin model" may also vary with environmental factors. MacCall (1990) showed that in California, the distribution area of sardine and anchovy populations shrinks in periods of very low abundance. Then spawning is restricted to the more favourable spawning sites, which maintain minimal sustaining conditions for these populations. In contrary, in period of high abundance, the

25 population extends over most of the potential spawning area. The basin model suggests that spawning habitat selection depends on population size (Density dependent Habitat, $\mathrm{DDH})$. According to this model, our results suggest that the recurrent spawning centres located in the Gironde and Adour plumes may constitute refuge basins for the maintenance of the anchovy population in the Bay of Biscay.

Anchovy and sardine spawning area

For the two periods of study, the spatial structure of anchovy spawning may be characterised by a "continuous area" located in the south of the continental shelf contrary to the more patchy distribution of sardine all over the area cover by the survey. 
This feature has also been reported in other regions of the world as in the Benguela upwelling (van der Lingen et al., 2001) or off California (MacCall, 1990, Lynn, 2003, Curtis, 2004). The apparent continuous spatial distribution of anchovy can be linked to the behaviour of adult populations which migrate less than sardine and are generally confined to areas of high productivity (Bakun and Broad, 2003). The patchy distribution of sardine spawning is likely linked to sardine greater swimming capabilities and flexibility towards food resources (Parrish et al., 1989, Checkley et al., 2000, Bakun and Broad, 2003, Lynn, 2003). In fact, recurrent spawning sites of anchovy and sardine are spatially disctinct. Anchovy recurent sites are located in coastal waters and occasionaly in offshore waters. Conversely, sardine recurrent sites are less coastal and one is located on the shelf break. Anchovy may be more restricted to near shore areas than sardine habitat because of smaller size and inferior swimming ability (Dotson and Griffith, 1996) and high eggs abundance seems to prevail in either coastal well mixed areas or highly stratified river plumes (Planque et al., submitted). In contrast, sardine is

15 part of population that expands largely beyond Bay of Biscay (Furnestin and Furnestin, 1959, Ettahiri et al., 2003), so the superior swimming ability of sardine may allow organisation at larger scales and greater movement during spawning. Therefore, possible influence of hydrographic factors on the spawning habitat seems less clear than anchovy (Planque et al., submitted). Hence, the differences observed between recurrent spatial patterns of sardine and anchovy eggs reflect the behaviour of spawning adults may be governed by several interacting variables like population size, age structure, tolerance to hydrographic factors, flexibility towards food ressource and swimming ability. 


\section{CONCLUSION}

The combined use of presence/absence indices, geostatistics and mixed-effect models appear to be adequate to produce realistic descriptions of the "realised spawning habitats" for sardine and anchovy, as well as a characterisation of their interannual and

5 long-term variability. Spawning habitat for both species can be divided into recurrent, occasional or unfavourable sites, on the basis of interannual variations in egg spatial distributions. Sardine spawning habitat is fragmented, appears spatially limited by the presence of the cold pool and confined to coastal and shelf break areas in years of restricted spawning extent. Anchovy spawning predominantly occurs in river plume

10 areas, which may constitute refuge basins for the maintenance of anchovy population in the Bay of Biscay, but can expand further offshore in years of more intense spawning. For both species, the mean patterns of spawning have changed between 1967-1972 and 2000-2004. This is particularly visible for the anchovy population which has experienced a general offshore and northward extension in the recent years. Whether

15 this trend reflects changes in population size and demography, changes in environmental conditions, changes in the seasonal timing of observations or a combination of these still needs to be addressed. Further investigation on variations in hydrological conditions and adult population structure are needed to elucidate this question. 


\section{REFERENCES}

Agostini, V. N. and Bakun, A. (2002) 'Ocean triads' in the Mediterranean Sea: physical mechanisms potentially structuring reproductive habitat suitability (with example application to European anchovy, Engraulis encrasicolus). Fish. Oceanogr. 11: 129-142.

Allain, G., Petitgas, P., Grellier, P. and Lazure, P. (2003) The selection process from larval to juvenile stages of anchovy (Engraulis encrasicolus) in the Bay of Biscay investigated by Lagrangian simulations and comparative otolith growth. Fish. Oceanogr. 12: 407-418.

10 Allain, G., Petitgas, P. and Lazure, P. (2001) The influence of meso-scale ocean processes on anchovy (Engraulis encrasicolus) recruitment in the Bay of Biscay estimated with a three-dimensional hydrodynamic model. Fish. Oceanogr. 10: 151-163.

Anonymous (1997) Proceedings of the international symposium on the role of forage fishes in marine ecosystems, Anchorage, Alaska 13-16 November 1996. University of Alaska Sea Grant College Program Report. N 97-01. Lowell Wakefield Fisheries Symposia Series N¹4. ISBN-1-56612-049-7. 816pp.

Arbault, S. and Lacroix, N. (1971) Aires de ponte de la sardine, du sprat et de l'anchois dans le golfe de Gascogne et sur le plateau Celtique. Résultats de 6 années d'études. Rev. Trav. Inst. Pêches Marit. 35: 35-56.

Arbault, S. and Lacroix, N. (1977) Oeufs et larves de clupeides et engraulides dans le golfe de Gascogne (1969-1973). Distribution des frayères. Relations entre les facteurs du milieu et la reproduction. Rev. Trav. Inst. Pêches Marit. 41: 227-254.

Bakun, A. (1996) Patterns in the Ocean. Ocean processes and marine population dynamics. La Jolla: California Sea Grant College System, 323pp.

Bakun, A. and Broad, K. (2003) Environmental 'loopholes' and fish population dynamics: comparative pattern recognition with focus on El Niño effects in the Pacific. Fish. Oceanogr. 12: 458-473. 
Barange, M. and Hampton, I. (1997) Spatial structure of co-occuring anchovy and sardine populations from acoustic data: implications for survey design. Fish. Oceanogr. 6: 94-108.

Borja, A., Uriarte, A., Egaña, J., Motos, L. and Valencia, V. (1998) Relationships between anchovy (Engraulis encrasicolus) recruitment and environment in the Bay of Biscay (1967-1996). Fish. Oceanogr. 7: 375-380.

Borja, A., Uriarte, A., Valencia, V., Motos, L. and Uriarte, Ad. (1996) Relationships between anchovy (Engraulis encrasicolus L.) recruitment and the environment in the Bay of Biscay. Sci. Mar. 60 (Suppl. 2): 179-192.

10 Boyra, G., Rueda, L., Coombs, S. H., Sundby, S., Adlandsvisk, B., Santos, M. and Uriarte, A. (2003) Modelling the vertical distribution of eggs of anchovy (Engraulis encrasicolus) and sardine (Sardina pilchardus) Fish. Oceanogr. 12: 381-395.

Brown, J. H. (1984) On the relationship between abundance and distribution of species. Am. Nat. 124: 255-279.

Checkley, D. M. J., Dotson, R. C. and Griffiths, D. A. (2000) Continuous, underwaysampling of eggs of Pacific sardine (Sardinops sagax) and northern anchovy (Engraulis mordax) in spring 1996 and 1997 off southern and central California. Deep Sea Res. 2 47: 1139-1155.

20 Checkley, D. M. J., Ortner, P. B., Cummings, S. R. and Settle, L. R. (1997) A continuous underway fish eggs sampler. Fish. Oceanogr. 6: 58-73.

Cressie, N. A. C. (1993) Statistics for spatial data. Revised Edition. New York: Wiley Inter-science, 900pp.

Curtis, K. A. (2004) Fine scale spatial pattern of pacific sardine (Sardinops sagax) and northern anchovy (Engraulis mordax) eggs. Fish. Oceanogr. 13: 239-254.

Cury, P. (1988) Pression sélectives et nouveautés évolutives : une hypothèse pour comprendre certains aspects des fluctuations à long terme des poissons pélagiques côtiers. Can. J. Fish. Aquat. Sci. 45: 1099-1107.

Cury, P., Bakun, A., Crawford, R. J. M., Jarre, A., Quiñones, R. A., Shannon, L. J. and

Verheye, H. M. (2000) Small pelagics in upwelling systems: patterns of 
interaction and structural changes in "wasp-waist" ecosystems. ICES J. Mar. Sci. 57: 603-618.

Cury, P. and Roy, C. (1989) Optimal environmental window and pelagic fish recruitment success in upwelling areas. Can. J. Fish. Aquat. Sci. 46: 670-680.

5 Cushing, D. H. (1975) Marine Ecology and Fisheries. Cambridge University Press, $278 \mathrm{pp}$.

Doston, R.C. and Griffiths, D. A. (1996) A high-speed mid-water rope trawl for collecting coastal pelagic fishes. CalCOFI Rep. 37: 134-139.

Ettahiri, O. Berraho, A., Vidy, G. Ramandi, M. and Do chi, T. (2003) Observation on the spawning of Sardina and Sardinella off the south Moroccan Atlantic coast $\left(21^{\circ}-26^{\circ} \mathrm{N}\right)$ Fish. Res. 60: 207-222.

Furnestin, J. and Furnestin, M. L. (1959) La reproduction de la sardine et de l'anchois des côtes Atlantiques du Maroc (saisons et aires de pontes). Rev. Trav. Inst. Pêches Marit. 23: 79-114

15 González-Quirós, R., Pascual, A., Gomis, D. and Anadón, R. (2004) Influence of mesoscale physical forcing on tropic pathways and fish larvae retention in the central Cantabrian sea. Fish. Oceanogr. 13: 351-364

Guisande, C., Cabanas, J. M., Vergara, A. R. and Riveiro, I. (2001) Effect of climate on recruitment success of Atlantic Iberian sardine Sardina pilchardus. Mar. Ecol. Prog. Ser. 223: 243-250.

Hammann, M. G., Nevarez-Martinez, M. O. and Green-Ruiz, Y. (1998) Spawning habitat of the Pacific sardine (Sardinops sagax) in the Gulf of California: egg and larval distribution 1956-1957 and 1971-1991. CalCOFI Rep. 39: 169-179.

Hjort, J. (1914) Fluctuations in the great fisheries of Northern Europe viewed in the light of biological research. Rapp. P.-v. Réun. Cons. int. Explor. Mer 20: 1-20.

Junquera, S. (1986) Changes in the anchovy fishery of the Bay of Biscay in relation to climatic and oceanographic variations in the North Atlantic. Proceedings of the International Symposium on Long term changes in Marine Fish Populations, Vigo (Spain), 543-554. 
Koutsikopoulos, C. and Le Cann, B. (1996) Physical processes and hydrological structures related to the Bay of Biscay anchovy. Sci. Mar. 60 (Suppl. 2): 9-19.

Lindstrom, M. J. and Bates, D. M. (1990) Nonlinear mixed effects models for repeated measures data. Biometrics 46: 673-687.

5 Lloret, J., Palomera, I., Salat, J. and Sole, I. (2004) Impact of freshwater input and wind on landings of anchovy (Engraulis encrasicolus) and sardine (Sardina pilchardus) in shelf waters surrounding the Ebre (Ebro) River delta (northwestern Mediterranean). Fish. Oceanogr. 13: 102-110.

Lluch-Belda, D., Crawford, R. J. M., Kawasaki, T., MacCall, A. D., Parrish, R. H., Schwartzlose, R. A. and Smith, P. E. (1989) World-wide fluctuations of sardine and anchovy stocks : the regime problem. S. Afr. J. mar. Sci. 8: 195-205.

Logerwell, E. A. and Smith, P. E. (2001) Mesoscale eddies and survival of late stage Pacific sardine (Sardinops sagax) larvae. Fish. Oceanogr. 10: 13-25.

Lynn, R. J. (2003) Variability in the spawning habitat of Pacific sardine (Sardinops sagax) off southern and central California. Fish. Oceanogr. 12: 541-553.

MacCall, A. D. (1990) Dynamic geography of marine fish populations. Washington: University of Washington Press, 153pp.

Marinoni, O. (2003) Improving geological models using a combined ordinary-indicator kriging approach. Envir. Geol. 69: 67-45.

20 Matheron, G. (1962) Traité de Géostatistique appliquée. Paris: Bureau de recherches géologiques et minières, $171 \mathrm{pp}$.

Motos, L. (1996) Reproductive biology and fecundity of the Bay of Biscay anchovy population (Engraulis encrasicolus L.) Sci. Mar. 60 (Supl. 2): 195-207.

Motos, L., Uriarte, A. and Valencia, V. (1996) The spawning environment of the Bay of Biscay anchovy (Engraulis encrasicolus L.). Sci. Mar. 60 (Supl. 2): 117-140.

Parrish, R. H., Serra, R. and Grant, W. S. (1989) The monotypic sardines, Sardina and Sardinops: their taxonomy, distribution, stock structure and zoogeography. Can. J. Fish. Aquat. Sci. 46: 2019-2036.

Petitgas, P. (1993) Use of disjunctive kriging to model areas of high pelagic fish density in acoustic fisheries survey. Aquat. Liv. Res. 6: 201-209. 
Petitgas, P., Massé, J., Grellier, P. and Beillois, P. (2003) Variation in the spatial distribution of fish length: a multi-annual geostatistics approach on anchovy in Biscay 1983-2002. ICES CM 2003/Q:15: 14pp.

Pingree, R. D. and Le Cann, B. (1992) Three anticycloic Slope Water Oceanic eDDIES (SWODDIES) in the southern Bay of Biscay in 1990. Deep Sea Res. 1 39: 11471175.

Pinheiro, J. C. and Bates, D. M. (2000) Mixed-Effects Models in S and S-plus. Springer, $528 \mathrm{pp}$.

Planque, B., Beillois, P., Jégou, A. M., Lazure, P., Petitgas, P. and Puillat, I. (2003) Large scale hydroclimatic variability in the Bay of Biscay. The 1990s in the context of interdecadal changes. ICES Marine Science Symposia 219: 61-70.

Planque, B., Bellier, E. and Lazure, P. (submitted) Modelling potential spawning habitat of sardine (Sardina pilchardus) and anchovy (Engraulis encrasicolus) in the Bay of Biscay.

Puillat, I., Lazure, P., Jégou, A. M., Lampert, L. and Miller, P. (2004) Hydrographical variability on the French continental shelf in the Bay of Biscay during the 1990's. Cont. Shelf Res. 24: 1143-1164.

R Development Core Team (2004) $R:$ A language and environment for statistical computing. R Foundation for Statistical Computing. Vienna, Austria.: ISBN 3900051-00-3, URL http://www.R-project.org.

Reid, J. L. (1966) Oceanic environment of the genus Engraulis around the world. CalCOFI Rep. 11: 29-33.

Ribeiro, J. R. and Diggle, P. J. (2001) geoR: A package for geostatistical analysis. $R$ NEWS 1: ISSN 1609-3631. Available for download at: http://cran.rproject.org/doc/Rnews.

Schwartzlose, R. A., Alheit, J., Bakun, A., Baumgartner, T. R., Cloete, R., Crawford, R. J. M., Fletcher, W. J., Green-Ruiz, Y., Hagen, E., Kawasaki, T., Lluch-Belda, D., Lluch-Cota, S. E., MacCall, A. D., Matsuura, Y., Nevárez-Martínez, M. O., Parrish, R. H., Roy, C., Serra, R., Shust, K. V., Ward, M. N. and Zuzunaga, J. Z. (1999) Worldwilde large-scale fluctuations of sardines and anchovy populations. South African Journal of marine Science. 21: 289-347. 
Sinclair, M. (1988) Marine populations. An essay on population regulation and speciation. University of Washington Press Seattle and London. Washington Sea Grant Program, 252pp.

Somarakis, S., Palomera, I., Garcia, A., Quintanilla, L., Koutsikopoulos, C., Uriarte, A., Motos, A. (2004) Daily egg production of anchovy in European waters. ICES J. Mar. Sci. 61: 944-958.

Stradoudakis, Y., Bernal, M., Borchers, D. L. and Borges, M. d. F. (2003) Changes in the distribution of sardine eggs and larvae off Portugal, 1985-2000. Fish. Oceanogr. 12: 49-60.

10 Uriarte, A., Prouzet, P. and Villamor, B. (1996) Bay of Biscay and Ibero Atlantic anchovy populations and their fisheries. Sci. Mar. 60 (Suppl. 2): 237-255.

van der Lingen, C. D., Hutchings, L., Merkle, D., van der Westhuizen, J.-J. and Nelson, J. (2001) Comparative spawning habitats of anchovy (Engraulis capensis) and sardine (Sardinops sagax) in the southern Benguela upwelling ecosystem. In Spatial processes and management of marine populations. University of Alaska Sea Grant College Program, Anchorage Alaska: 185-209.

Vincent, A. (1973) Les variations de la situation thermique dans le golfe de Gascogne en 1969 et 1979. Rev. Trav. Inst. Pêches Marit. 37: 5-18.

Vincent, A. and Kurc, G. (1969a) Hydrologie, variations saisonnières de la situation thermique du Golfe de Gascogne en 1967. Rev. Trav. Inst. Pêches Marit. 33: 7996.

Vincent, A. and Kurc, G. (1969b) Les variations de la situation thermique dans le golfe de Gascogne et leur incidence sur l'écologie et la pêche de la sardine en 1968. Rev. Trav. Inst. Pêches Marit. 33: 203-212. 
Table 1. Variogram model parameters for sardine and anchovy for the two periods, combined fixed and random effects are highlighted in grey, fixed only effects are shown in white.

\begin{tabular}{|c|ccc|ccc|}
\hline & \multicolumn{3}{|c|}{ SARDINE } & \multicolumn{3}{c|}{ ANCHOVY } \\
\hline year & nugget & sill & range & nugget & sill & range \\
\hline 1967 & 0.034 & 0.238 & 33.917 & 0.089 & 0.233 & 136.015 \\
1969 & 0.149 & 0.087 & 33.917 & 0.089 & 0.186 & 136.015 \\
1970 & 0.074 & 0.184 & 33.917 & 0.089 & 0.088 & 136.015 \\
1971 & 0.161 & 0.070 & 33.917 & 0.089 & 0.016 & 136.015 \\
1972 & 0.095 & 0.157 & 33.917 & 0.089 & 0.191 & 136.015 \\
\hline 2000 & 0.053 & 0.144 & 25.703 & 0.102 & 0.097 & 45.773 \\
2001 & 0.093 & 0.174 & 25.703 & 0.102 & 0.162 & 45.773 \\
2002 & 0.019 & 0.197 & 25.703 & 0.102 & 0.175 & 45.773 \\
2003 & 0.066 & 0.152 & 25.703 & 0.102 & 0.213 & 45.773 \\
2004 & 0.074 & 0.173 & 25.703 & 0.102 & 0.075 & 45.773 \\
\hline
\end{tabular}




\section{FIGURE LEGENDS:}

Fig 1. Fish egg sampling plan over the Bay of Biscay : Network station during "historical cruise" in 1971 (triangle) and CUFES sampling midpoint (dots) during the cruise PELGAS2001. The location of Loire, Gironde, Adour estuaries, Brittany and coast of les Landes are indicated.

Fig 2. Dates of research cruises "Hydrologie-pêche" (1967 to 1972) and "Pelgas" (2000 to 2004).

Fig 3. Theoretical variograms adjusted to experimental variograms by Nlme method for sardine (top) and anchovy (bottom) for the two period of study. Plain lines: theoretical variogram with only fixed effect; dotted line : theoretical variogram with fixed and random effects; points: empirical variogram estimates.

Fig 4. Spatial distribution "realised spawning habitat" of sardine (top) and anchovy (bottom) in 1967, 1969, 1970, 1971, 1972 and in 2000, 2001, 2002, 2003, 2004. Grey scale is proportional to the probability of egg presence.

Fig 5: Spatial location of recurrent, occasional and unfavourable sardine spawning area; top left: average map of sardine spawning area for the period of 1967-72 (Grey scale is proportional to the average probability of presence of eggs); top right: variability map of sardine spawning area for the period of 1967-72 (Grey scale is proportional to the standard deviation of the probability of presence of eggs); bottom left: average map of sardine spawning area for the period of 2000-04; bottom right: variability map of sardine spawning area for the period of 2000-04.

Fig 6.: Spatial location of recurrent, occasional and unfavourable anchovy spawning area; top left: average map of anchovy spawning area for the period of 1967-72 (Grey scale is proportional to the average probability of presence of eggs); top right: variability map of anchovy spawning area for the period of 1967-72 (Grey scale is proportional to the standard deviation of the probability of presence of eggs); bottom left: average map of anchovy spawning area for the period of 2000-04; bottom right : variability map of anchovy spawning area for the period of 2000-04. 


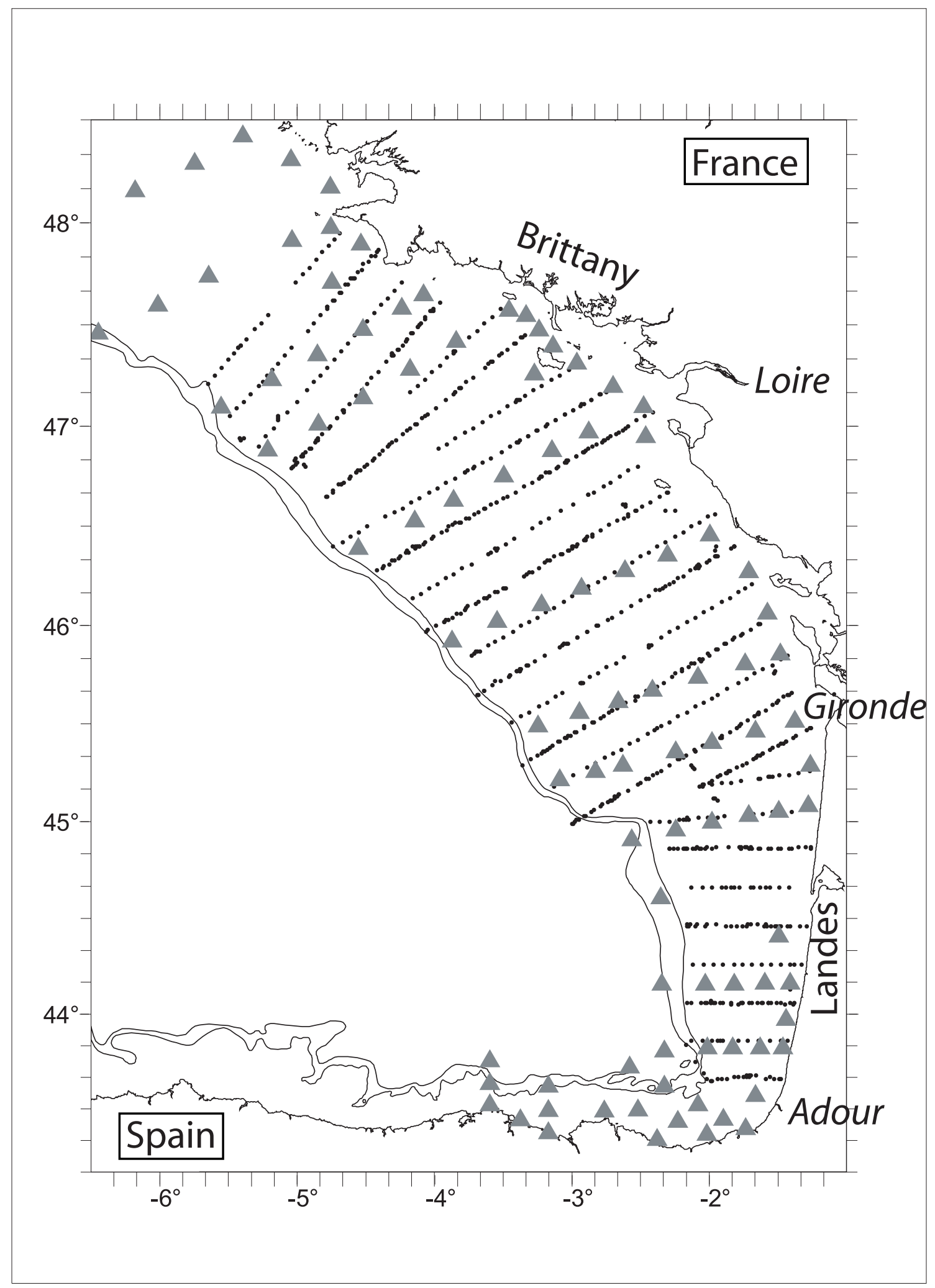




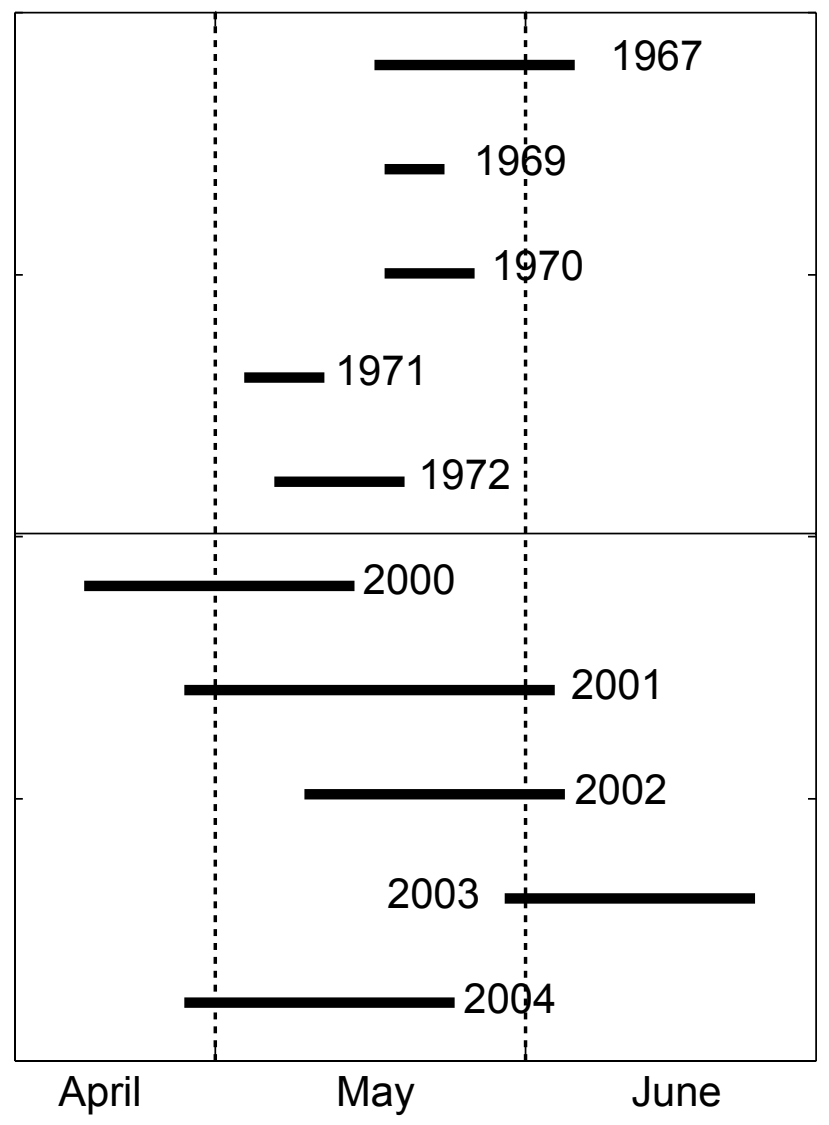

Figure 2 

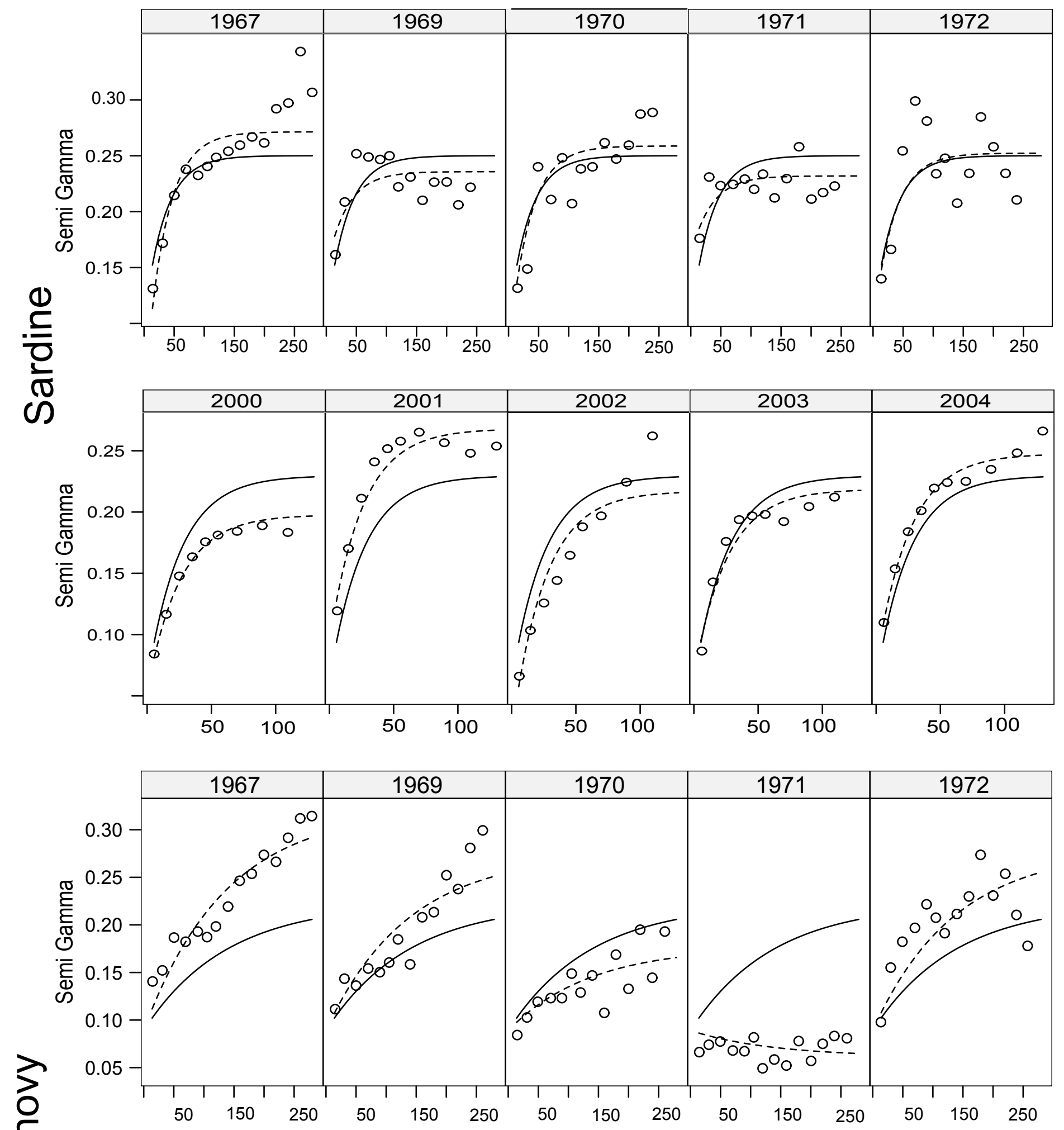

Figure 3

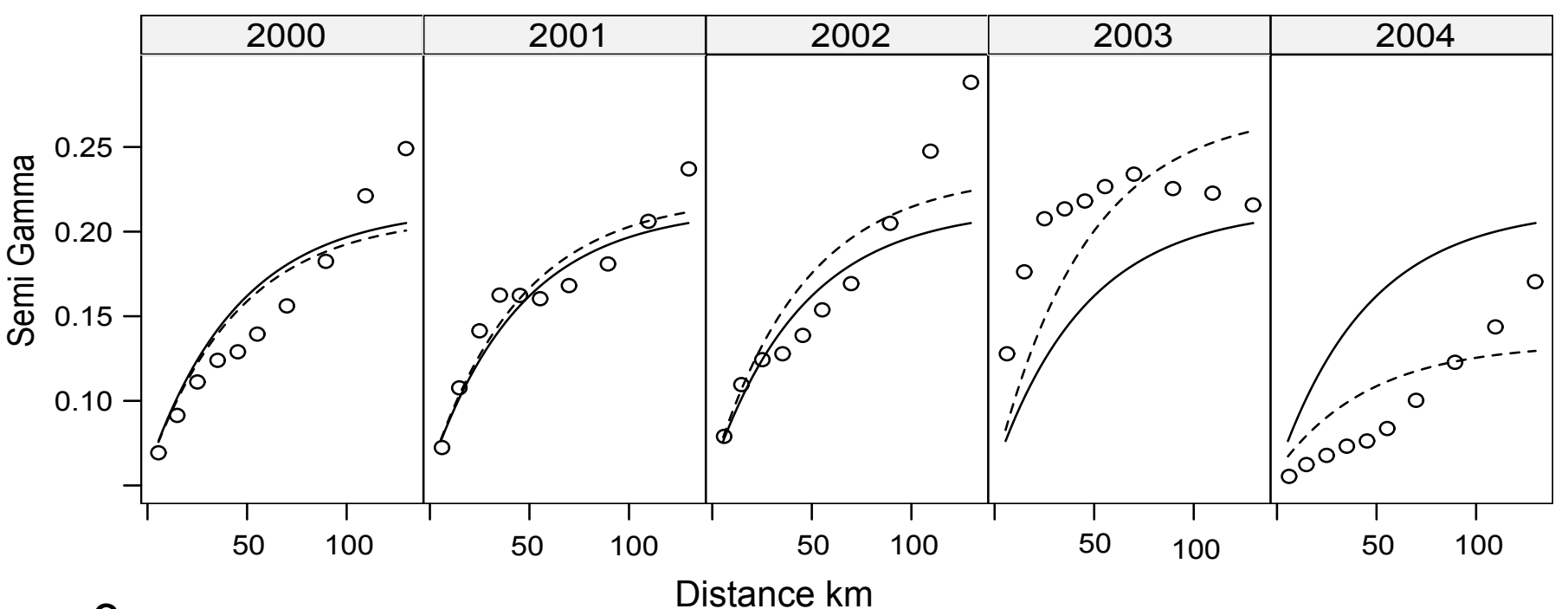



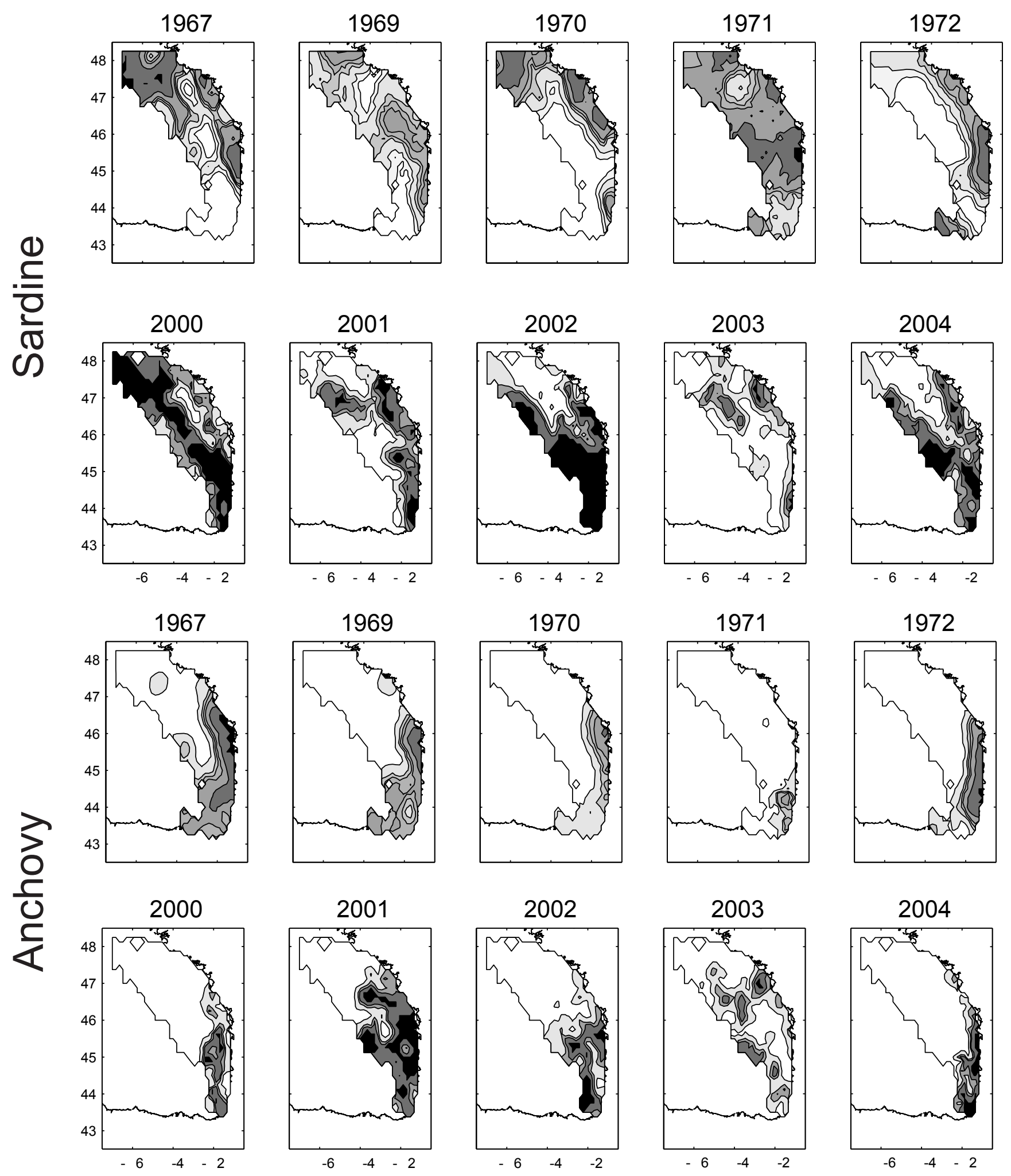

Figure 4 


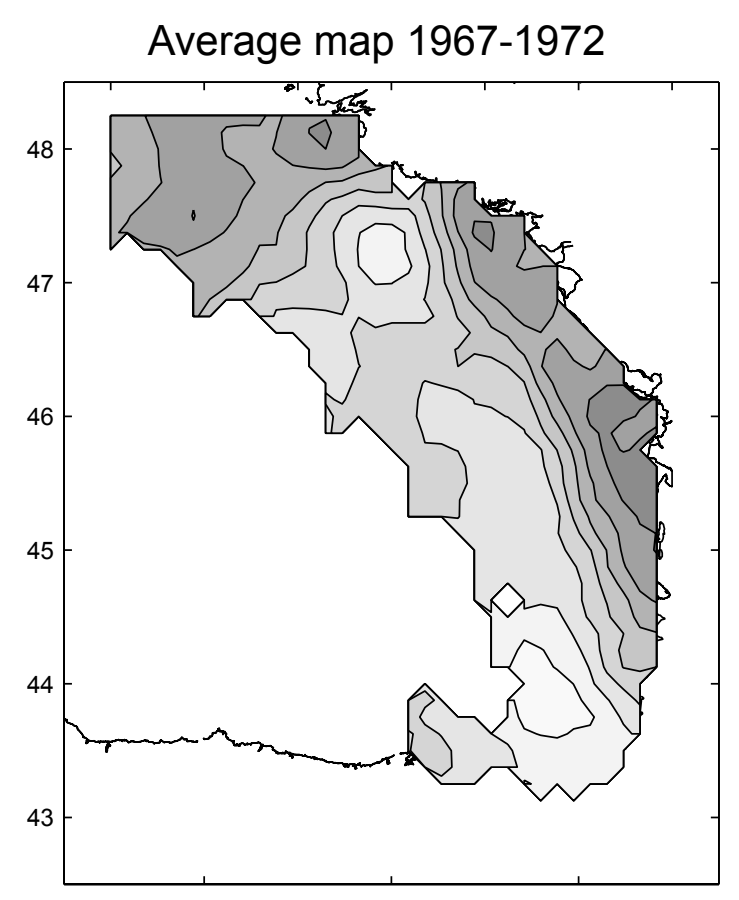

Average map 2000-2004
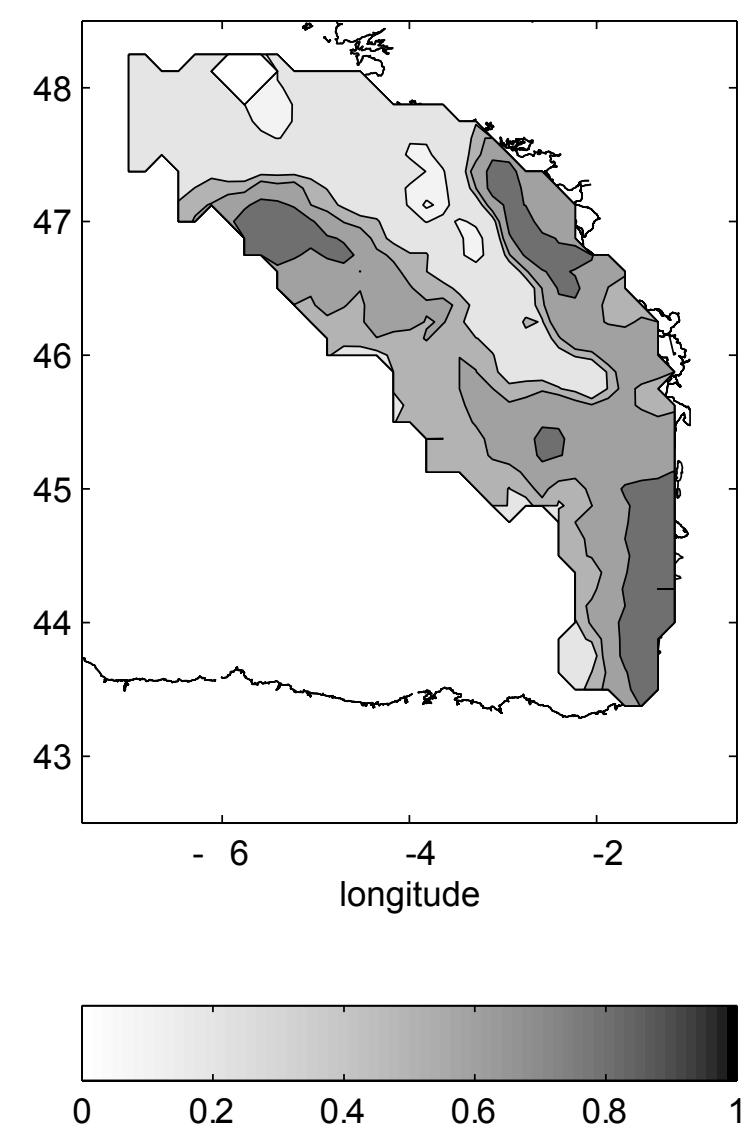

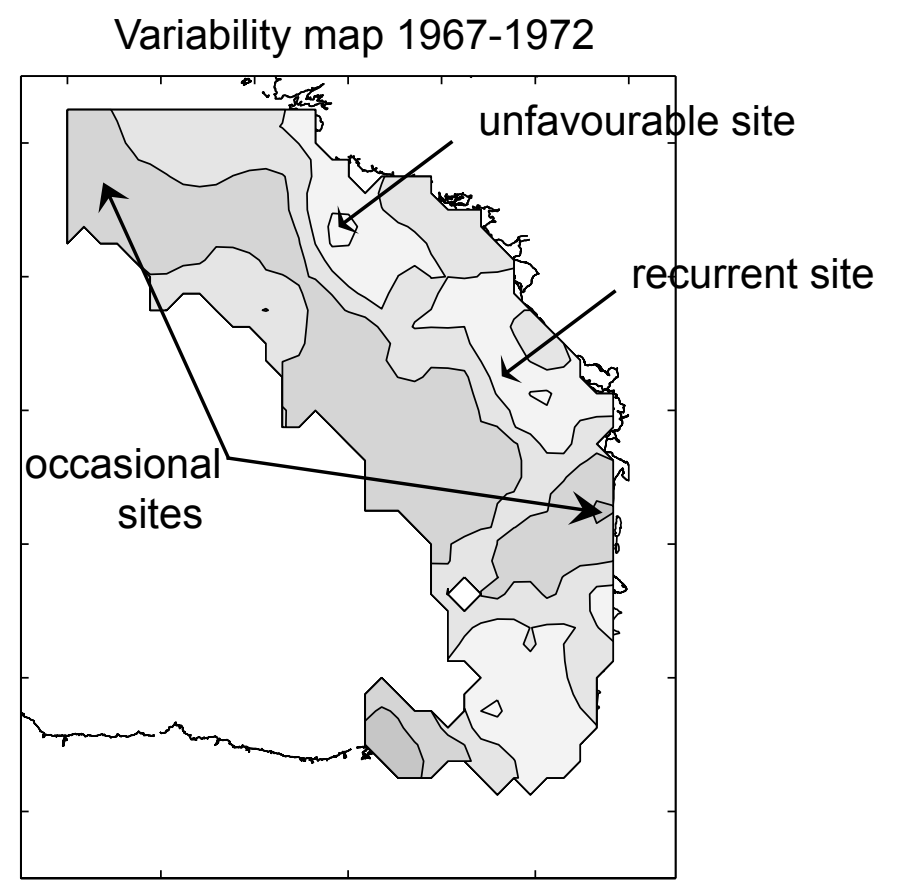

Variability map 2000-2004
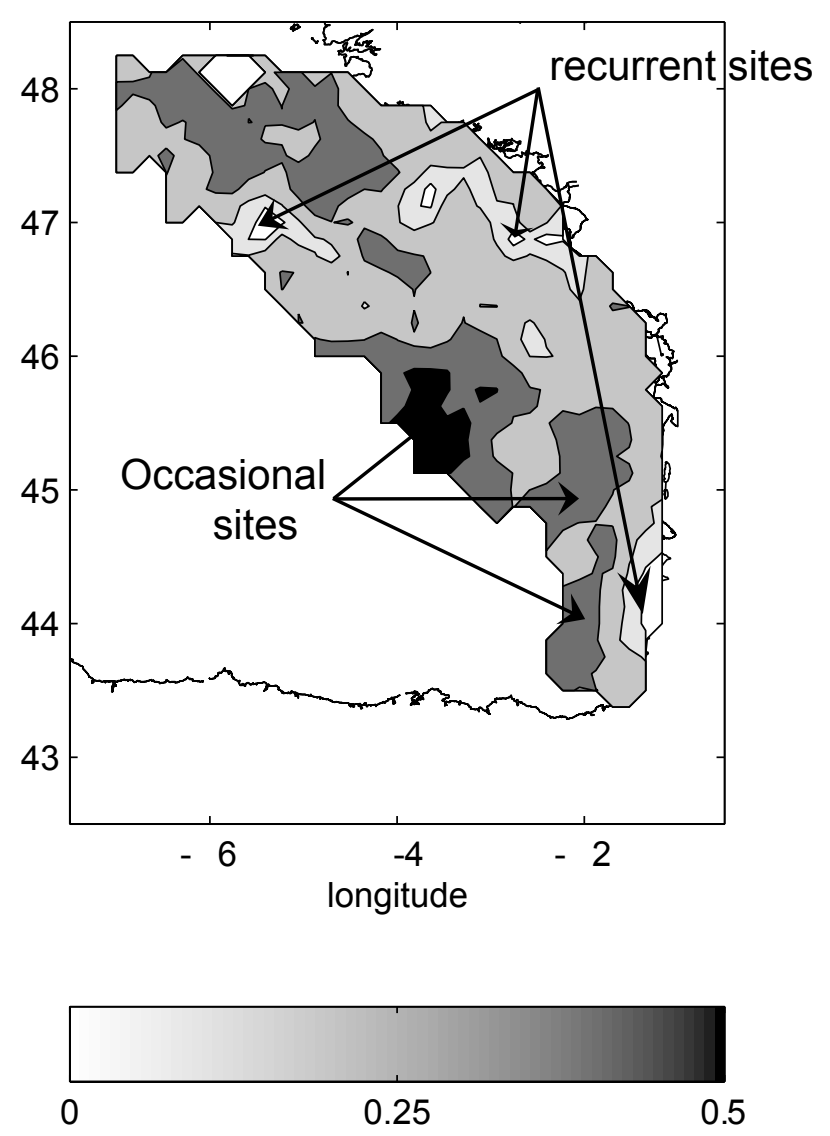

Probability of eggs presence

Figure 5 

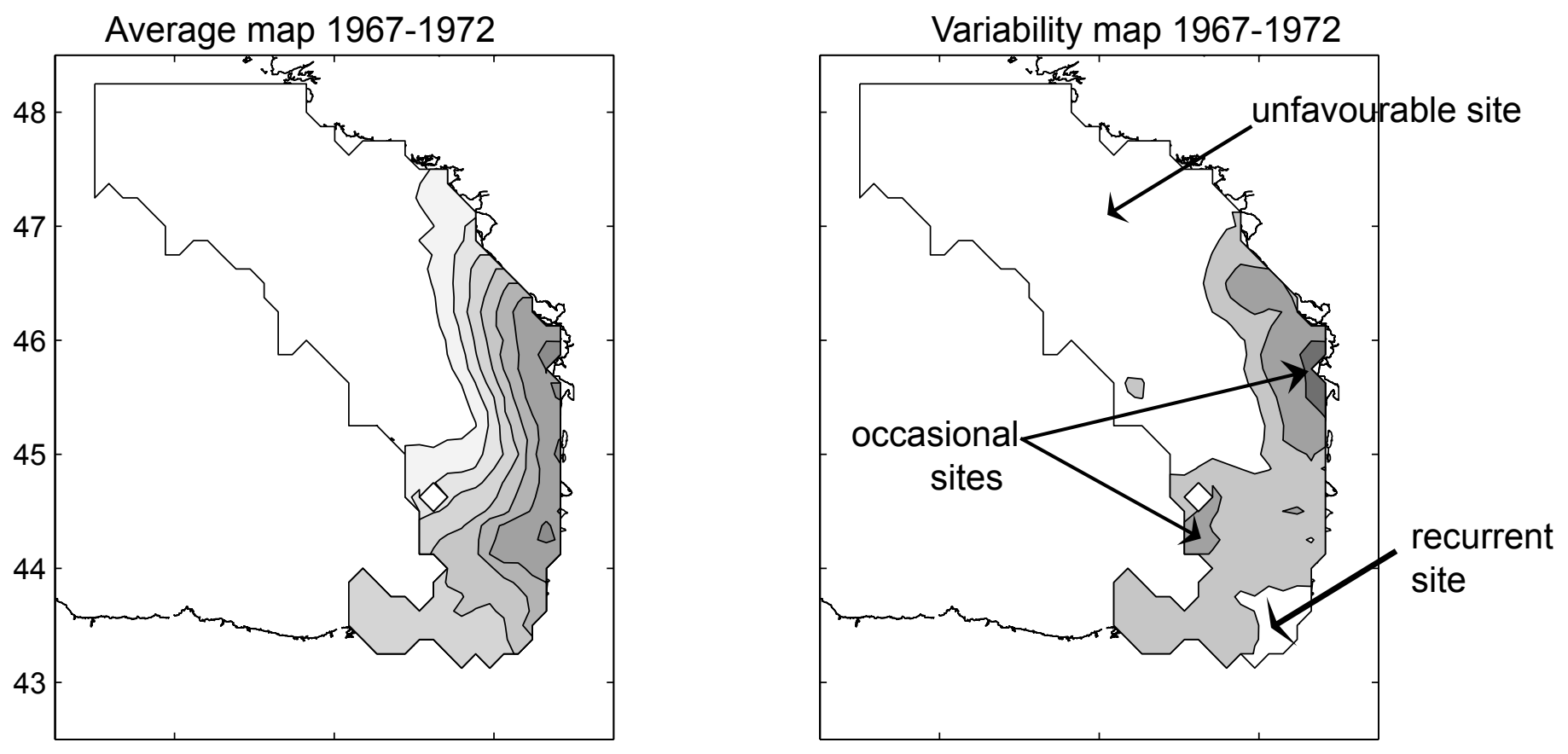

Average map 1967-1972

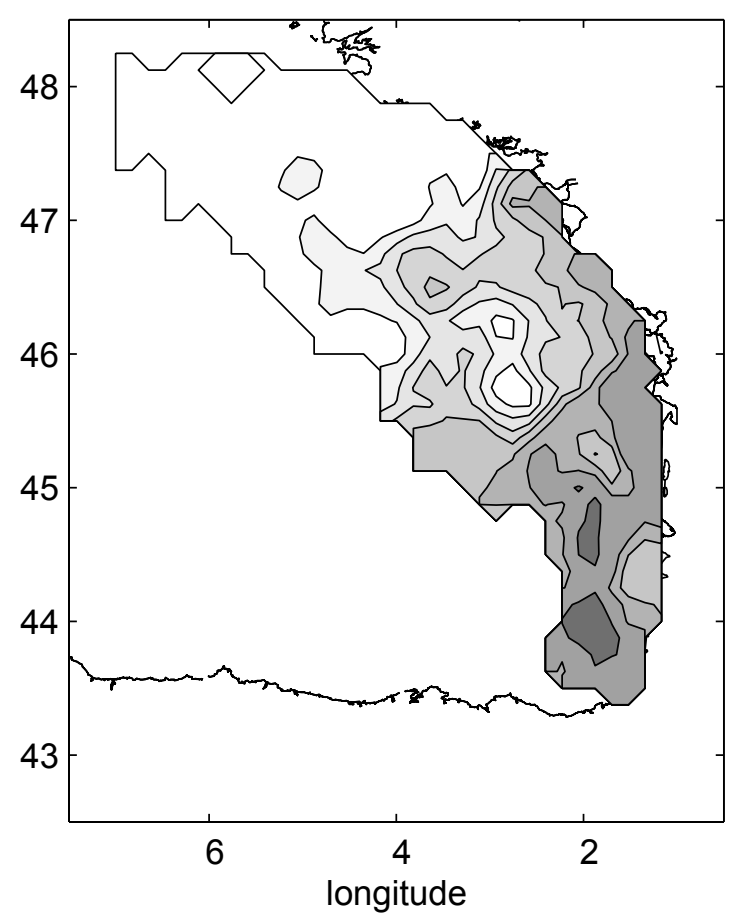

Variability map 1967-1972
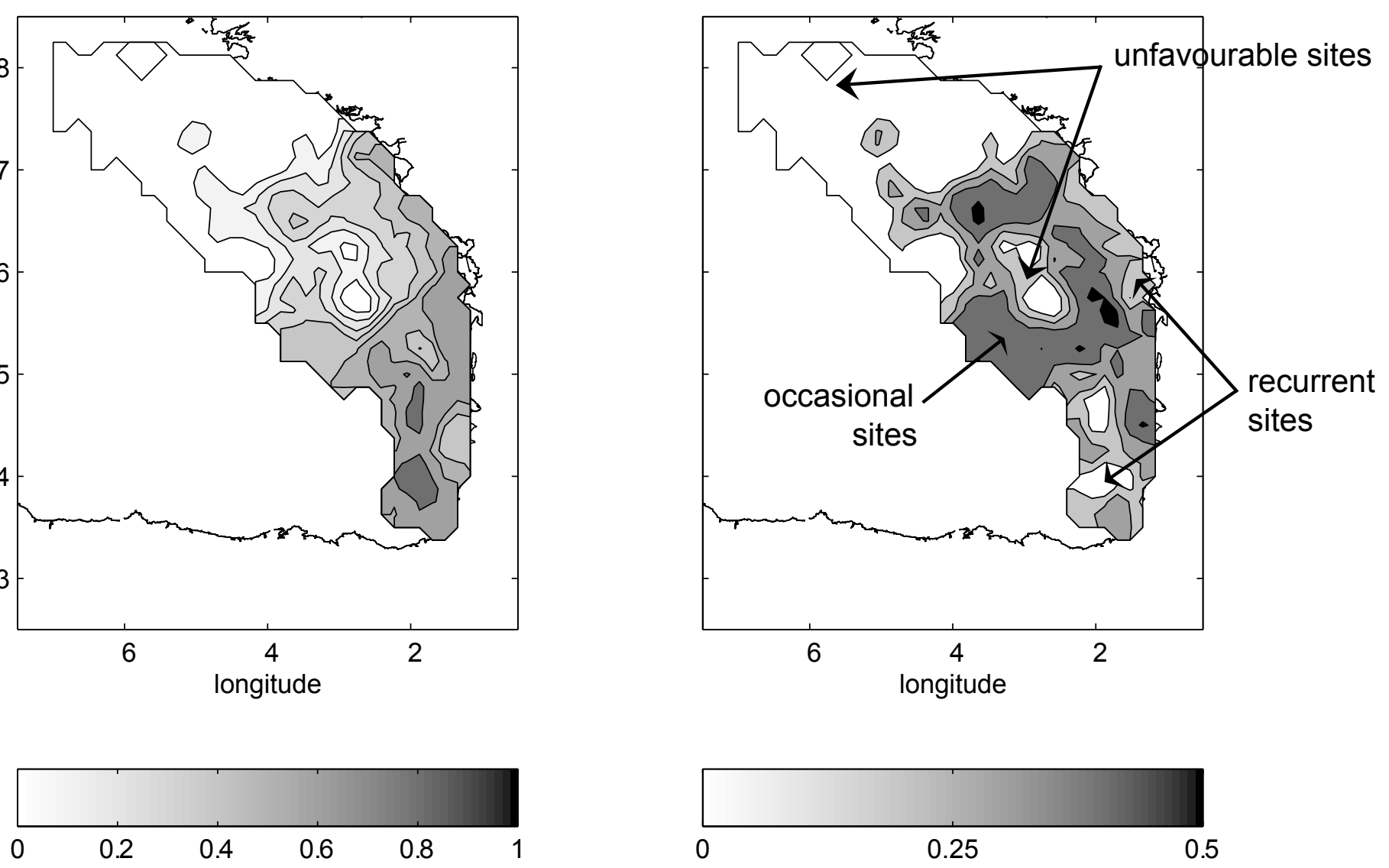

Probability of eggs presence 